\title{
Power and Legitimacy in International Politics: Britain and Germany's Responses to the U.S.'s Wars Against Iraq in 1991 and 2003
}

\author{
Afrimadona \\ Northern Illinois University
}

\begin{abstract}
The paper evaluates the constructivist claim that legitimacy embedded in a country's foreign policy shapes the responses of other countries' foreign policy. I test the claim using four cases of Britain's and Germany's responses to US's invasion in Iraq in 1991 and 2003. The choice of US's invasion in Iraq in 1991 and 2003 was made on the ground that the latter was regarded as utterly illegitimate due to a lack of UN's authorization. Thus, both cases reveal a variation in the extent of legitimacy (positive versus negative cases). My observation of Britain's and Germany's foreign policy responses is based on the fact that both countries are US's allies. Thus, by examining allies' responses to US's invasion in Iraq in these two periods, I control for countries' type of relationship with the US that may affect their behavior towards the country. My observation shows that only one out of the four cases (Germany's response to US's invasion in 2003) supports the claim that legitimacy is the main concern underlying states' foreign policy response. In general, this study also suggests that legitimacy may matter under normal situation. During crises, however, states tend to be more pragmatic and power-based explanation seems more convincing.
\end{abstract}

Keywords: Britain, Germany, Iraq, legitimacy, U.S.

\begin{abstract}
Abstrak
Tulisan ini mengevaluasi klaim konstruktivis bahwa legitimasi yang terdapat dalam sebuah kebijakan luar negeri suatu negara membentuk respon kebijakan luar negeri negara-negara lain. Penulis menguji klaim tersebut menggunakan empat kasus respon Jerman dan Inggris terhadap invasi Amerika Serikat di Irak pada tahun 1991 dan 2003. Pemilihan invasi Amerika Serikat di Irak pada tahun 1991 dan 2003 dibuat atas dasar bahwa invasi tahun 2003 dinilai secara umum tidak terlegitimasi berkaitan dengan kurangnya otorisasi Perserikatan Bangsa-Bangsa. Maka, kedua kasus menyingkap variasi dalam jangkauan legitimasi (kasus positif lawan kasus negative). Observasi penulis atas respon kebijakan luar negeri Jerman dan Inggris didasarkan pada fakta bahwa kedua negara merupakan sekutu Amerika Serikat. Oleh karena itu, dengan mengamati respon para sekutu terhadap invasi Amerika Serikat di Irak dalam dua periode ini, penulis membatasi diri pada tipe hubungan negara-negara dengan Amerika Serikat yang mungkin memengaruhi perilaku mereka terhadap Amerika Serikat. Pengamatan penulis menunjukkan hanya satu dari empat kasus (respon Jerman terhadap invasi Amerika Serikat pada tahun 20o3) yang mendukung klaim bahwa legitimasi merupakan perhatian utama yang mendasari respon kebijakan luar negeri negara-negara. Secara umum, studi ini juga menyiratkan legitimasi mungkin berarti di bawah situasi normal. Namun, selama krisis, negara-negara cenderung untuk menjadi lebih pragmatis dan penjelasan berdasarkan kekuasaan tampak lebih meyakinkan.
\end{abstract}

Kata kunci: Inggris, Jerman, Irak, legitimasi, Amerika Serikat. 


\section{Introduction}

This paper departs from theoretical question on whether states respond to other countries' foreign policy based on material incentives or legitimacy. This is an important theoretical question in the light of increasing attention to international norms in international relations theory and especially regarding consensus among scholars that the efficacy of American power is highly related to its legitimacy (Hurd, 2007: 194).

This paper will test the constructivist's hypothesis to states' foreign policy. Constructivists assume that the effectiveness of a state's action does not merely follow from a logic of consequences, but also from logic of appropriateness. This means that a state can achieve its foreign policy's goals by implementing not only cost-effective instruments, but also norms-compatible instruments. Seen as being legitimate, a country's foreign policy will be supported by other countries and this facilitates the working of the policy and the attainment of its objectives.

I will test this hypothesis with cases where a country attempts to use the same foreign policy instrument at different times which lead to different levels of success in terms of influencing others. There are two questions I need to answer to investigate the theory's logic. First, do target states consider the sender's use of the foreign policy instrument as legitimate or not? Second, do they support policies regarded as compatible with international norms and oppose policies regarded as violating them? If I get affirmative response to these questions, I will investigate causation using both primary sources (speeches of the country's leaders, official documents, etc) and secondary sources. In particular, I will investigate whether states supported the policy because they felt that it was legitimate and opposed it because they perceived it as illegitimate. I will also investigate whether alternative explanations such as material incentives or pragmatism provide better explanations for the cases.

I will test this theory by comparing Britain's and Germany's responses to U.S invasion in Iraq in 1991 and 2003. The choice of the U.S.'s invasions at these two periods are appropriate because on the surface, this same foreign policy yielded different results in terms of international support. Comparing Britain and Germany is also appropriate because these two allies of the U.S. demonstrate different levels of support for the policy at these two periods of cases.

I organize the paper into five sections. The first section will be devoted to define key terms I use throughout the paper. Second section will elaborate theoretical perspective underlying the testing process to be done in the paper. In the third section, I will explain methodological issues on how to test the hypothesis and collect data. In the fourth section, I will test the hypothesis and explain the causal logic by exploring two cases of American invasion of Iraq and compare Britain's and Germany's response to them. In the concluding section, I will summarize my observation and evaluate the generalization of the findings. I will also compare the theory's explanation of the cases with other alternative explanation and evaluate their relative explanatory powers.

\section{Definitions of Key Terms}

Before going on to elaborate theoretical exposition and test the theory, I will define some key terms to be used in this paper. The first term is legitimacy. Legitimacy refers to "a generalized perception or assumption that the actions of an entity are desirable, proper, and appropriate within some socially constructed system of norms, values, beliefs, and definitions" (Suchman, 1995: 574). Thus, in international politics, an action can be regarded as legitimate if it is seen as desirable, proper, and appropriate by members of international community. The basis for assessing the appropriateness of an action is international norms, rules, and principles (Reus-Smit, 2007: 159). Borrowing from Krasner, we can define principles as "beliefs of fact, causation, and rectitude." Norms refer to "standards of behavior defined in terms of rights and obligations." And rules are "specific prescriptions or proscriptions for actions" (Krasner, 1982: 186). These norms, principles, and rules constitute "collective expectation about proper behavior for a given identity" (Jepperson, Wendt, \& Katzeinstein, 1996: 54). 
Thus, states' actions are considered as proper and appropriate if those actions are within the limits of their rights and obligations and in accordance with agreed rules. States doing what they are entitled to or doing what they are obliged to do can be regarded as legitimate. Otherwise, international community will regard it as illegitimate.

As argued by Reus-Smit, legitimacy is a social concept in that it requires social approval by the community in which an actor lives. Status as a legitimate actor or action is conferred by the community and not by the actor itself. An actor may engage in the practices of legitimation, seeking to justify its identities, interests or actions by refering to particular norms, but this legitimacy claim will not necessarily lead to his or her commanding legitimacy. He or she is regarded as being legitimate only when community regards his or her claim as "rightful within the political realm in which the actors seek to act" (Reus-Smit, 2007: 160).

However, legitimacy is different from legality, rationality or morality. When the community calls an action as being illegitimate, the action is not necessarily irrational, illegal or immoral. An action is called rational when it is regarded as costefficient in achieving an objective within existing strategic constraints. An action is considered legal when it is in accord with "a relevant body of legal doctrine" regardless of public rejection or hostitlity to this action. Finally, an action can be regarded as moral if it conforms to a favored moral philosophy. Even though all these values are used to justify the legitimacy of an action, the existence of these values does not necessarily produce legitimate action. An action is legitimate when it is socially sanctioned (Reus-Smit, 2007: 160). Yet, they can be the basis of assessing legitimate or illegitimate actions.

Although legitimacy of an action is based on norms, rules, and principles, all these elements of institutions can also be assessed as being legitimate or not based on their rightfulness. A rule, for example, can be regarded illegitimate when it serves the interest of the powerful at the expense of general interests of the community. Similarly, when a rightfulness of a norm diminishes constantly, then public may regard it as illegitimate. The degree of legitimacy of a rule, norm, or principle is also subject to change. When a rule or norm is violated constantly and the community tolerates it, then the rule or norm will gradually change. Old rules or norms will become illegitimate and new rules or norms will replace them. In short, legitimacy assessment applies to both rules and actors (rulers). Only if both are regarded as legitimate will the subjects obey the command of the rulers (Weber in Franck, 1988: 709).

Legitimacy may also affect identity and interest. Identity is "relatively stable, rolespecific understandings and expectations about self" (Wendt, 1992: 396). Identity is shaped by social norms coming either from international system or domestic sources. Mostly, these norms are injected or introduced by individuals or civil society organizations (Klotz, 1995; Finnemore \& Sikkink, 1998). Individuals promote new norms through "organizational platform" that they created in order to give broader impact on the constituents they address (Finnemore \& Sikkink, 1998: 899). When these norms are adopted by states, they will define states' identities and interests. When these identities are stable, public will assess states' behavior based on the identities they agreed. It is in this situation that domestic public will see the coherence of states' behavior with their identities. Based on this shared identities, public will define what particular behavior is regarded as proper and desirable based on the identities they adopt.

\section{Theoretical Overview: Constructivist's View on Legitimacy as Source of Power}

Constructivism is a social theory rather than a susbtantive one. As a social theory, it mainly concerns the relationship between agent and structure. However, it does not specify what unit and structure are. In IR, the social theory rival for constructivism is rationalism. That is why in many textbooks, scholars explain constructivism by juxtaposing it with rationalism (Reus-Smit, 2005; Barnett, 2008). Like constructivism, rationalism is also a social theory which explains the relations between agent and structure. It also does not specify its agent and structure. The task of specifying 
these is taken by substantive theories. Susbtantive theory tries to explain a particular domain and develop propositions on the domain. As a domain-specific, it needs to specify agent and structure of the domain (Wendt, 1999: 6). Thus, neorealism, for example, is a substantive theory because it tries to explain particular aspects of international politics, develop specific propositions on them, specify what actors and structure to focus on and explain the relationship between the two.

As a social theory, constructivism has a specific way of understanding the nature of agent and structure and their relationships. The essence of constructivism is "social construction of world politics" (Price \& ReusSmit, 1998: 266). There are some basic assumptions shared by constructivists scholars. First, social structure is shaped by both material and ideational elements. The most important factors in ideational element are shared understanding, expectation, and knowledge (Wendt, 1995: 73). Constructivist's emphasis on these three ideational components of social structure reflects its idealist ontology. To constructivism, shared ideas, beliefs, and norms have powerful effect on social and political actions (Reus-Smit, 2005: 196). Yet, it does not mean that constructivists ignore material structure. Constructivists recognize that such material elements as mountains, geography, and weapons are real and 'out there'. But, they have no meaning for human action without shared understanding on the materials. An interesting example is given by Alexander Wendt: the U.S. fears five North Korean nuclear weapons more than five hundred British nuclear weapons simply because British is the American friend while North Korea is not. Shared understanding covering institution of friendship (amity) between the U.S. and Britain and institution of enmity between the U.S. and North Korea shapes Americans' view on the material instruments the two countries possess (Wendt, 1995: 73).

Second, identities constitute interests and actions (Price \& Reus-Smit, 1998: 267). Identities are essentially shaped by ideational structure. Shared understanding about particular behavior constitutes actors' identities in their social interaction: a country is identified as democratic when it allows public voice in policy making process. Otherwise, it will be viewed as authoritarian. Identities in turn shape interests and actions. In contrast to rationalism that perceives states' identities and interests as given, constructivism sees interests as being subject to change. The change in the U.S's. interests in the 1980s, for example, can explain the development of new international sanctions against South African apartheid regime. The change in American interests regarding interracial discrimination in South Africa was shaped by the new transnational norms on anti-racial discrimination that in turn shaped the U.S.'s identity as a democracy. As a democracy, the U.S. should support racial equality and this means intolerance against racial discrimination in South Africa (Klotz, 1995).

Third, constructivists believe that agent and structure are mutually constitutive. This means that on the one hand, structure shapes actors' identities, interests, and actions. On the other hand, social structure can exist only through the practice of these actors. Once these actors cease this practice, the structure will be over. The four decades of the Cold War structure existed because the two superpowers behaved hostilely to one another. Once they stopped practicing competitive foreign policy, the Cold War was over (Wendt, 1995: 74).

Finally, social construction of reality shapes criteria for legitimate and illegitimate actions. This implies that an action is assessed based on logic of appropriateness instead of logic of consequences. Logic of appropriateness assesses an action based on its conformity to agreed norms or rules while logic of consequences assesses an action based on its effectiveness in achieving its goal. For constructivists, these two logics of actions are not in contradition to one another. Instead, they can be mutually supportive. An action regarded as illegitimate will not be supported by other countries. Thus, it needs more effort and is increasingly costly to work out. In short, an action regarded as flaw in light of the logic of appropriateness, will be inefficient in terms of the logic of consequences (Barnett, 2008: 163). 
From the assumptions above, we can derive constructivist version of power. Constructivists in general understand power as "legitimate capacity" comprising both capacity and "a right to act" based on the consent of those controlled (Reus-Smit, 2004: 43). Power in this context contains two notions: right and legitimacy. Understanding power this way gives it four features. First, power is relational in that it is gained only through social interaction. An actor is said to have power if it can transform the behavior of others in favor of its interests. Second, power is "primarily ideational" where it is mainly composed of social institutions, commonly defined as "complexes of norms, rules, principles and decision-making procedures”. Materially, nuclear weapon is the most powerful weapon in the world. Yet, the norm of "nuclear taboo" makes it less effective as a source of power (Tannenwald, 1999: 434). Third, this sort of power is "inter-subjective" because in order to be powerful, there should be shared ideas about what is considered as "powerful" and what is not. It is impossible to control or influence adversary that does not believe in the strength of certain actor's weapons. Deterrence can be effective if the adversaries believe in their respective credibility of using force. Fourth, it is "social" in that it results from collectively regularized practices and social institutions (Reus-Smit, 2004: 43-44).

Understanding power this way recognized the embeddedness of power in "exchange and reciprocal adaptation" between parties (Reus-Smit, 2004: 57). Hence, power needs to be negotiated continuously so that it can constitute stable rule. However, the exercise of this kind of power depends so much on the legitimacy of the actors. It is in this context that legitimacy plays important role. Legitimacy as the basis of power can command obedience by audience and subsequently amplify the opportunity of one's will to prevail in a social relationship (Weber in Bereskoetter, 2007: 4). At this situation, power in its transformative sense, that is "the ability to affect the outcomes you want, and if necessary, to change the behavior of others to make this happen" (Nye, 2002: 4) can be evident.

In the realm of international relations, "the core principles of legitimacy express rudimentary social agreement about who is entitled to participate in international relations, and also about appropriate forms in their conduct" (Clark, 2005: 4). Legitimate actor involved in international community will have a chance to negotiate its interests and position in its social relationships with others. In this international setting, legitimacy plays very important role as a source of power. Nevertheless, the strength of legitimacy needs to be upheld by institutions (Reus-Smit, 2007: 159).

Institutions determine power through three ways. First, institutions give meaning to the exercise of power. For example, under the institution of friendship, building new weapons system will help increasing the security of allies. Under the institution of rivalry, however, this new weapons system is viewed as endangering the security of adversaries. Second, institutions legitimate power. The use of force is forbidden unless it is authorized by the U.N. Security Council (U.N.S.C.). Third, institutions help regularizing and stabilizing power relations by limiting particular forms of actions regarded as disturbing to the system. All kinds of institutions, from constitutive institutions like sovereignty, to fundamental institutions such as international law and multilateralism, to international regime like NPT, perform this function (Reus-Smit, 2004: 61).

States having legitimacy can enjoy three benefits. First, it can easily gain support from others related to the decision it makes or the project it runs. This support is sometimes not only in the form of simple compliance, but also in the form of joint operation or active involvement in the project it designed. The support given by many countries to American leadership in the first U.S.'s invasion in Iraq was attributable to shared idea that the action was legitimate in the context of the norms of collective security. The legal basis for the action supported by majority of the U.N. Security Council's members strengthened the legitimacy of the action and gave militarily capable countries no reasons for not participating (Moore, 1992). Second, it can shape the behavior of others in line with its rule, decisions, or policies. And third, it can scale down the level of opposition thus 
"reduces the cost of coercion and bribery" (Reus-Smit, 2007: 163-164).

Legitimate action can shape power relations through public pressure or public resistance (Barnett \& Duvall, 2005: 22-23). Through discourse, shared understanding about the desirability of an action will emerge and this will eventually shape policy choices to make by the government. As suggested by Finnemore and Sikkink (Finnemore \& Sikkink, 1998) and Kloz (Kloz, 1995), the role of nonstate actors was very important in this situation. Both international institutions or private individual can be norm entrepreneurs that shape the way public see an action and push their governments to support or reject the action.

\section{Methodology}

To test the constructivist hypothesis, I will use controlled comparison ${ }^{1}$ and investigate paired observations in two cases: Britain and Germany's foreign policy responses to U.S.'s foreign policy instrument in Iraq in 1991 and 2003. In both cases, both independent and dependent variables are the same. The independent variable is American war policy against Iraq and the dependent variable is Britain's and Germany's response to American war policy. However, there is a variation in the independent variable. In the first U.S invasion in 1991, there was the U.N.S.C.'s authorization for the war while in the second invasion in 2003, there was no such U.N.S.C.'s resolution to authorize the war. I will see whether or not the responses of the two countries (Britain and Germany) vary according to this U.N.authorized U.S. policy. In the methodological parlance, I will investigate the degree of congruence or incongruence of the independent and dependent variables in the two cases. There are two aspects I am going to observe here. The first is whether or not Britain and Germany responded to U.S. war policy based on legitimacy consideration. The main indication I will look for to verify this is whether or not foreign policy response was given after the U.N.S.C.'s resolution had been passed (for the first invasion). This is a legal basis for assessing the legality of the war. As I mentioned above, legality is different from legitimacy. Yet, legality is the basis for assessing legitimacy. If countries approve a resolution allowing an action to be done, it means that they give authority to the action. An action equiped with authoritative power is regarded as legitimate (Reus-Smit, 2004: 5859). If a foreign policy response is given after a resolution is passed, we can suspect that the response might be caused by legitimacy consideration. Otherwise, it might not. However, for the second invasion, due to the absence of the U.N.S.C.'s resolution, we could simply observe whether or not there was any support given to the U.S.'s policy against Iraq.

If the foreign policy response is given after a resolution is passed, then we will investigate whether legitimacy consideration causes it. To verify it, I will see the discourse that occured during the period leading up to the decision to respond the war. Public discourse is one of the most important causal mechanism suggested by constructivists to see whether or not a policy is made based on legitimacy. Although we might argue that leaders taking a decision under public pressure are not genuine (they want popular support for election for example), legitimacy still affects their decision indirectly. This is because public pushes them to make decisions based on the social desirability and normativeness of the targeted policy. Here, protest or public pressure is an intermediate variable that links independent and dependent variables.

The primary sources to consult are memoirs, minutes, and transcripts of speech of leaders. I will also complement the information by consulting secondary sources such as news reports, books, and journal articles. News reports are especially important to describe the events that have yet to be revealed by official documents. However, due to a language problem, I cannot directly access the memoirs of Schroeder and Fischer. Instead, I got them

${ }^{1}$ For controlled comparison method in theory-testing model, see Van Evera (van Evera, 1997); George and Bennet (George \& Bennet, 2005). 
from the translation published in a series of articles by Spiegel Online. The data to be found in these sources are details of the events leading up to the decision made by states, the extent of material capability changes (e.g., whether or not changes in policy response are caused by economic factors like depression, fiscal cut, etc), and the level of public support.

\section{Case Studies}

\section{The First U.S.'s Invasion 1991: Introduction}

The first U.S.'s invasion in Iraq began with Iraq's incursion into Kuwait on August 2, 1990. Kuwait is a small and rich country on the northewestern shore of the Persian Gulf neighboring with Iraq to the north. Many argued that Iraq's invasion was motivated by economic factors: Iraq's budget deficit due to eight years of Iraq-Iran war, Kuwait's oil overproducing violating OPEC's quota discipline, and Kuwait's slant-drilling into Iraq's Rumaila oil field (Simon, 2004: 339340). With massive military force, Iraqi military occupied Kuwait completely within days. International community found this action intolerable because it violated international law. U.N. Security Council passed Resolution 660 which condemned the action and demanded withdrawal of troops immediately. Yet, the Iraqi government resisted. U.N. Security Council then passed Resolution 661 on August 6, 1990 which enacted economic sanction against Iraq. This was followed immediately by Resolution 662 on August 9, 1990 (Moore, 1992: 26; Finlan, 2003: 29).

The Iraqi government responded by holding foreign nationals as hostages. Again, the U.N.S.C. passed Resolution 663 demanding that foreign nationals be released and access by consular officials to their nationals be opened (Moore 1992: 27). On August 25, 1990, U.N.S.C. passed Resolution 665 authorizing naval blockade to implement the economic sanctions. Although diplomatic efforts were undertaken and Iraq agreed to withdraw from Kuwait in return for simultaneous resolution for all occupation cases in the region, the Bush's administration rejected it (New York Times, $13^{\text {th }}$ August 1990:
A8). In fact, any diplomatic means undertaken by Iraqi government were rejected by the U.S. The U.S. wanted the Iraqi government to withdraw their troops unconditionally (Royce, 1991: 5; Friedman, 1990). As diplomatic solution and several U.N.S.C.'s resolutions failed to force Iraqi troops to withdraw from Kuwait, the Security Council issued Resolution 678 on November 29, 1990, with 12 nations voting for, 2 nations voting against, and one country abstain which authorized "member states cooperating with the Government of Kuwait" to use "all necessary means" to enforce the Security Council Resolution on the Gulf crisis unless the Iraqi government withdrew their troops from Kuwait before January 15, 1991 (Moore, 1992: 34).

War against Iraq was waged by the U.S. and supported by several countries after last diplomatic chance failed in Geneva in the early January 1991 (Friedman, 1991; Matthews, 1993: 106). A coalition of 34 nations launched attack against Iraq on January 7, 1991 based on the U.N.S.C. Resolution 678. Among the supporters of this war were Britain and Germany. Britain contributed 35,000 troops; 300 tanks with supporting logistics and equipments; 69 combat aircrafts; 5 destroyers; 6 frigates; 8 minehunters; 5 logistics landing ships, 2 ocean survey ships; 6 replenishment ships; 6 air squadrons, and 3 helicopter groups. Meanwhile, Germany contributed 19 ships and substantial amount of financial support, around USD 6.6 billion (CNN, 2001; Matthews, 1993: 62). The next section will explain the reason for the two countries to participate in the war.

\section{Britain's Participation in the first U.S's Invasion}

Britain's decision to join the war was made immediately after Iraq's invasion into Kuwait was launched. In fact, Prime Minister Margareth Thatcher had demonstrated her 'hawkish' position on the issue even before the Bush's administration made tough decision on it (The Economist, $1^{\text {st }}$ September 1990: 51). Thatcher argued that the use of force against Iraq did not require any further Security Council's authorization because Article 51 of the U.N. Charter on state's right for selfdefense has been enough to justify it (Webster 
1990; Haas 2009: 71). When the idea of forming multinational force emerged on early August 1990, Britain was the first country to decide its contribution and joined the U.S. in deploying troops to stop Iraq's invasion (Frankel, 1990: A37). Britain even demanded that its European allies be involved and more support for the U.S. in the law enforcement against Iraq be given (Wood \& Bremner, 1990: 1).

It is difficult to attribute Britain's involvement in the U.S.- led coalition forces on the legitimacy of the use of force by the U.S. as constructivism predicted. This is because Thatcher and her administration designed the possible plan of using of force since the beginning. Immediately after Iraq's invasion occured, Britain and the U.S. gathered international support in the Security Council to pass a series of resolutions that condemned the invasion and enacted economic sanctions against Iraq. In a joint press conference held in Aspen, Colorado, on August 6, 1990, Thatcher demonstrated tougher stance on the issue than President Bush. Her referencing to Chapter 7 of the U.N. Security Council repeatedly in the conference indicated her thinking of the possibility of the use of force in the case (transcript, Aspen Institute, $2^{\text {nd }}$ August 1990).

Britain's tougher stance on Iraq's invasion of Kuwait was also evident in the domestic support for the war compared to that in the U.S. Domestically, Thatcher's campaign for the war was supported quite enthusiastically. Cabinet meeting held immediately upon Thatcher's return to London agreed Britain's contribution of some forces to the anti-Iraq coalition. This decision was made even before President Bush formally announced the U.S.'s position on the formation of a multinational force (Freedman \& Karsh 1993: 112). Futhermore, Britain's public support for the use of force was also stronger. A survey conducted before the war indicated that the support for the use of force against Iraq was 49 per cent, compared to 43 per cent approving more sanctions but short of force. When the war began, the support for the use of force increased to almost 90 per cent (Freedman \& Karsh, 1993: 347). The war debate in the House of Commons on January 15, 1991 was also not as bitter as the same debate in the U.S. Congress. In the vote on the war decision, 534-57 favored the use of force to enforce the law when the deadline was due. This was different from what occured in the U.S. The U.S. Senate voted $57-42$ for the the use of force while in the House of Representatives, the vote was 250-183 for the war policy (Dumbrell, 2006: 208).

As far as the U.S. was concerned, the diplomatic approach was still the prefered option at the early stage of Iraq's invasion. The U.S.'s attitude to some extent has led to dissatisfaction on the British side. Conservative MPs criticized the U.S. as too soft and warned of the U.S.'s retreat into isolationism. Ian Gilmour, a Conservative MP, even accused the U.S. of rewarding aggression (Dumbrell, 2006: 207). While the U.S. was still hesitant to get involved deeply in the fray, Britain's ardent war supporters even indicated that the war should aim at dethroning Saddam Hussein rather than merely liberating Kuwait (Freedman \& Karsh 1993: 347). Regime change has been the main issue in the war.

From the facts above, it was clear that Britain took more hawkish stance than the U.S. on the issue of Iraq's invasion of Kuwait. Although Britain supported the U.S.'s leadership in the war against Iraq in January 1991, it was obvious that the support was not based on the U.S.'s legitimate foreign policy. If legitimacy of U.S. foreign policy instrument regarding the Iraq's invasion was the basis of Britain's involvement in the war, then we would have found evidence that consideration of war was taken after the U.N.S.C. Resolution 678 was passed and it was the U.S., rather than Britain, that should have initiated the use of force on the issue. Yet, the facts showed otherwise. However, it is possible that consideration of illegitimate foreign policy instrument by Iraqi government could explain British position on the issue. To some extent, this can be seen from the argument made by PM Thatcher that "Iraq has violated and taken over the territory of a country which is a full member of the United Nations. That is totally unacceptable and if it were allowed to endure then there would be many other small countries that could never feel safe" (Press Conference transcript, Aspen Institute, $2^{\text {nd }}$ August 1990). 
Nonetheless, some interests might trump legitimacy argument. After all, since Bush came to power, the U.S. showed an inclination to focus on Germany (Freedman and Karsh 1993: 110). The shift in the U.S.'s priority away from Britain, especially since the retirement of Ronald Reagan, may disadvantage Britain. Britain's place in the world began to wane with the rise of unified Germany and thus, the crisis opened an opportunity for Britain to reassert its special position as a U.S.'s partner and also a world power. By being the first to join the multinational force, Britain wanted to show to the U.S. that it was a staunch ally that could be relied on (The Economist, ${ }^{\text {st }}$ September 1990: 23). Besides, economic interest may explain the British policy on the issue. Britain is an important economic partner of Kuwait. This close economic ties have occured since 1961 when British troops gave protection to the newly independent Kuwait against Iraqi threat. The rich Kuwait then established close economic relations with Britain and Kuwaiti investment has played significant part in the British economy (Freedman \& Karsh, 1993: 111). This indicates that material interests, rather than ideational, as constructivists claim, can still explain British foreign policy regarding the crisis in the Persian Gulf in 19901991.

\section{Germany's Participation in the Gulf War I}

Germany's support to the coalition forces came mostly in the form of financial support rather than military one. German initial contribution was announced after the U.S. Secretary of State James Baker's visit on September 15, 1990. After the meeting, German Chancellor Helmut Kohl pledged a financial commitment to support the coalition worth $\$ 2.1$ billion. Around $\$ 1.6$ billion would go the U.S. and the rest to support Egypt, Jordan and Turkey (The economist, 22 September 1990: 98). However, this contribution was regarded as too small compared to the contribution of other allies. Pressed to increase his support, Kohl then pledged an additional $\$ 5.5$ billion to the U.S. and about $\$ 550$ million to Britain. In total, Germany provided financial contribution around $\$ 1$ billion in 1990 and $\$ 11$ billion in 1991 (Goshko, 1991: A26; Kinzer, 1991: 15).

Due to several constitutional constraints, Germany could not make large miltary contribution. Germany just sent seven vessels (five minessweepers and two support ships) to the Mediteranean to support the U.S. Sixth Fleet and to replace American ships that have been deployed to the Gulf. Germany also deployed eighteen Alpha jets to protect Turkey, but they were limited to defensive purposes only. The other military contribution was limited to transfers of equipment taken from surplus stocks left by former East Germany (Bennet et al, 1994: 66). The lack of Germany's military contribution was attributed to the German Basic Law, especially Articles 2 and 24 confining German military forces to selfdefense and/or participation in "collective security" coalitions. However, it was debatable whether this international participation includes military actions beyond NATO's geographical areas (Freedman \& Karsh, 1993: 118; Börner, 1996: 62; Muller, 1992: 139-142).

$$
\text { What explains Germany's }
$$

participation in the war and its support to U.S.led coalition against Iraq in the Gulf war? Many evidences indicated that Germany's contribution to the U.S.- led coalition was driven more by the U.S. and other allies' pressure rather than the legitimacy consideration of the U.S.'s war. This can be seen from the timing of the financial commitment made by Germany. The commitment was first made early September when Chancellor Kohl called President Bush and pledged aid. Yet, at this time, Germany still looked reluctant due to potential cost of German unification and existing financial burden to the Soviet Union. The next few days after the U.S. Senate's called for more burdensharing by the U.S.'s allies, James Baker then visited Germany on September 15 and talked to Kohl and Foreign Minister Genscher on the issue. Immediately after the meeting, Kohl then made public announcement about Germany's commitment to contribute a total DM 3.3 billion in aid to Egypt, Jordan, Turkey, and the U.S. (Bennet et al, 1994: 67).

The timing of the announcement of Germany's financial contribution had been made far before Resolution 678 was passed by 
the U.N.S.C. authorizing the use of force. This means that Germany had been involved in the war plan since the beginning as what Britain had been. If the legitimacy was the basis of Germany's involvement in the war, we would find the evidence that the financial contribution should have been made only after the U.N.S.C. Resolution 678 was passed because this was the legal basis that justified the war. Yet, it was found that the commitment has been driven by the U.S. and other allies' pressure. In an interview, Kohl admitted indirectly that Germany's reputation was endangered "if the judgment around the world was that if there is money to be made they're here, but if the issue is taking responsibility they evade it" (cited in Freedman \& Karsh, 1993: 120). Although Kohl also emphasized that the context of German involvement was in support of the U.N.'s decisions, the timing of the policy announcement made immediately after Baker's visit and international pressure seemed to weaken legitimacy argument in favor of alliance's commitment hypothesis (Bennet, 1994: 67-68).

Alliance commitment also trumped legitimacy argument when we examined other financial and military commitments made by Germany in 1991 after the war broke. Kohl announced more aid on 30 January only after Baker met him and Genscher in Germany on January 8, 1991. And again, the commitment was made after U.S. congressmen criticized small contribution made by Germany. They contrasted Germany's $\$ 8$ billion aid to support transitional period of Soviet troops in East Germany as part of the deal with Soviet Union, with the lack of financial support for the U.S.'s operation in the Gulf (Freedman \& Karsh, 1994: 120). Finally, legitimacy argument was futher undermined by the fact that Germany's financial support was announced amids public rejection over the war (Kinzer, 1991: 17). The polls conducted on September 1990 showed

${ }_{2}^{2}$ President George W. Bush had actually harbored an obsession for regime change in Iraq since he was a presidential candidate. In the 2000 Presidential Candidate Debate in Wake Forest University, he stated that "The sanctions are being violated...He (Saddam) better not be or there's going to be a consequence should that only 33 per cent of Germans favored military contribution to the Gulf War. Majority of them, 54 per cent, were against German's military involvement in the war. Similarly, majority of the people (53 per cent) also rejected amandment of the constitution allowing military engagement, even under the U.N.'s enforcement actions, outside NATO's area (The Economist, 22 ${ }^{\text {nd }}$ September 1990: 98). If the legitimacy argument were correct, we should have found that Germany's government had not decided to support war or at least delayed its support until public opinion shifted. This clearly indicated that international pressure affected government decision more than public voice.

\section{The Second U.S.'s Invasion in 2oo3: Introduction}

The Second U.S.'s invasion in Iraq occured from March 19 until May 1, 2003. The war occured when the U.S. launched a major military action called "Operation Iraqi Freedom" supported by three countries: Britain, Australia, and Poland. The invasion was conducted after the Bush's administration accused Saddam Hussein of developing weapons of mass destruction (WMD) and cooperated with Al Qaida network. Although the United Nations Monitoring, Verification, and Inspection Commission (UNMOVIC) and International Atomic Energy Agency (IAEA) did not find any evidence that Iraqi government maintained and developed the weapons, the U.S. and Britain insisted otherwise and regarded Saddam Hussein as a dangerous threat to international security (Press Conference, $31^{\text {st }}$ January 2003). Citing Iraq's historical failure to comply with the U.N.S.C.'s Resolutions on previous WMD issues, Bush's administration urged for the regime change in Iraq. ${ }^{2}$ Despite worldwide protest against the U.S.'s invasion plan and military threats, Bush was determined to the

I be the president..." and when being asked whether he wished to remove Saddam, Bush responded, "I would like to, of course, and I presume this administration would as well...(Excerpt of Transcript of the 2000 Presidential Candidate Debate, October 11, 2000, cited in Mockaitis, 2012: 3). 
plan. Although diplomatic attempts were undertaken to gather support for the war, through Secretary of State Colin Powell's public presentation in the U.N.S.C., key allies (France, Germany, Turkey and Canada) and members of the U.N.S.C. did not support it. The war was eventually waged without the U.N.S.C.'s legal backing. The war was regarded as highly controversial and has divided the Trans-Atlantic alliance (Gordon \& Shapiro, 2004). Among the European supporters of war, Britain was the most ardent. In contrast, Germany was the main opponent in Europe. The following section will examine the foreign policy response by both Britain and Germany to the U.S.'s invasion policy and explained their different positions on the issue.

\section{Britain's Participation in the Second U.S.'s Invasion in Iraq}

Just as the Britain's involvement in the first invasion in 1991 came at the beginning, Britain's participation and decision to support the second U.S.'s invasion plan also came very early. As what Margareth Thatcher did in 19901991, Tony Blair was the first leader who together with George W. Bush and his national security team planned the invasion of Iraq to depose Saddam Husein. Although Blair had not made publicly a case for regime change in Iraq until his private meeting with Bush at his Crawford ranch in April 2002 (Sharp, 2003/2004: 64; Daily Mail, 27 ${ }^{\text {th }}$ November 2009), his minute to his chief of staff, Jonathan Powell and the U.K. Ambassador to the U.S., David Manning, suggested that he has began to be concerned with the threat of Saddam (Minute, $17^{\text {th }}$ March 2002). At this time, both felt that containment was no longer a viable strategy to eliminate Saddam's threat. Instead, regime change has become the main strategic option available.

Although Blair was committed to support Bush's policy towards Iraq, he still maintained his multilateralist position and focus on WMD issue rather than regime change because regime change could not be used to justify war. In a minute sent by Jonathan Powell to Blair on July 19, 2002, he reminded Blair of the difficulty for gathering support in the U.N. for invasion on the basis of the need for regime change (Minute, $19^{\text {th }}$ July 2002).
Together with Colin Powell, Blair then encouraged Bush to bring the plan of disarming Saddam to the U.N. On September 12, 2002, Bush made the case for war against Iraq if Saddam could not be disarmed. To support for Bush's position in the U.N., on 24 September 2002, Blair released "the hyped-up dossier" on Iraq WMD that successfully won unanimous support for Resolution 1441 calling on Saddam to accept U.N.'s inspectors and comply with all previous U.N.S.C. resolutions on its weapons programs or face severe consequences. Yet Resolution 1441 did not contain words, "take all necessary measures". Thus, for many members, this could not be used to justify the war (Sharp, 2003/2004: 65).

Blair's determination with war policy strengthened as indicated by his attempt to draft the U.N.'s resolution that authorized military action against Iraq. At this time, Blair had assumed that the inspections would fail to bring the expected results and devise alternative plan. The attempt failed because Germany, France, and Russia did not support it (Financial Times, 6 ${ }^{\text {th }}$ March 2003). In a memorandum sent to New York Times on February 25, 2003, the governments of the three nations stated that the case for the war was weak because the WMD was not found and Iraqi government had cooperated well. Rather than resorting to war, they proposed that more time and resources should be given to the inspection team to complete their tasks. They also supported for reinforced inspection and clear program of actions for the inspectors (New York Times, 25 ${ }^{\text {th }}$ February 2003: A14).

Mounting public rejection both domestically and in Europe did not undermine Blair's road to war. He even proceeded to the war plan although there would not be any U.N.S.C.'s resolutions authorizing the use of force. This unilateralist stance caused a crack in his cabinet. Government's Leader in the House of Commons, Robin Cook resigned from the cabinet on March 17, 2003 and in the following two days, seven government ministers and parliamentary secretaries also resigned (Sharp, 2003/2004: 67). Meanwhile, the British public also severely protested against the war plan. Bush then offered Blair an option of dropping out of the invasion for the sake of his government survival. Bush offered 
Blair another way of participating in the war "a second wave, peacekeeping or something" and was fine to go alone. But Blair refused this offer and indicated his willingness to join the U.S. in the war (Woodward, 2004: 338).

British road to war in 2003 clearly demonstrated that legitimacy was not the basis of its decision to support the U.S.'s foreign policy. The U.S.'s war plan was clearly illegitimate because it did not gain international support and the legal basis for the action, Resolution 1441, was debatable (New York Times, $1^{\text {st }}$ September 2002: 16). Blair's support for the war had been made even before Resolution 1441 was passed by the U.N.S.C. Blair's determination to the war plan despite domestic resistance also indicated that he neglected legitimacy consideration when making the decision. This was especially obvious when we saw the critiques raised by Robin Cook and Clare Short when they left the government. In a letter to Tony Blair, Short expressed her disappointment on the decision that was made without the U.N.'s mandate (The Guardian, 12 $2^{\text {th }}$ May 2003). The same reason was also expressed by Cook on March 17, 2003. He regarded the war as illegitimate due to its lack of international agreement and domestic support (BBC News, 18 ${ }^{\text {th }}$ March 2003).

\section{Germany's Position on U.S.'s Invasion in Iraq in 2003}

Germany, along with France and Russia, were the three most enthusiast opponents of American war against Iraq. Since the beginning, Germany had demonstrated its reluctance to the plan because of German pacifist identity that hates military approach in settling any conflicts (Kaim, 2003/2004: 135137). Besides, Germany refused the war plan because of its anxiety that the war would trigger instability in the region and spark a new and more intensified wave of terror against the West (Spiegel Online, $14^{\text {th }}$ November 2010). In a meeting between Bush and German Chancellor Schroeder on January 31, 2002, Schroeder signaled his support for Bush as

3 In his memoirs, Germany's then Foreign Minister, Joschka Fischer, recounted that when the two leaders long as the president took diplomatic route to handle Iraq problem or if an invasion were to be done, he would "stand reliably on the side of the U.S." if the U.S. could confirm "that Iraq was sheltering those responsible for the September 11 terrorist attacks" (The Telegraph, $10^{\text {th }}$ November 2010).

The divergence beween Germany and the U.S. began to harden when the U.S. changed its strategy over Iraq. Germany actually agreed that Saddam was a threat because of his cruel nature and suspected possession of WMD. However, different from the U.S., Germany believed that weakening Saddam's power by containing and disarming him of WMD is the best and safest strategy in responding to his threat. At the beginning, Bush also agreed with this. In a meeting in Washington between the two leaders, Bush also suggested that containment was still adopted and the U.S. would consult its allies when an action would be done or a strategic change would be made. In his memoirs, Bush admitted this saying that, "I told the German chancellor I was determined to make diplomacy work. I hoped he would help. I also assured him our words would not be empty. The military option was my last choice, but I would use it if necessary." (cited in Sporl \& Wiegrefe, 2010). Yet, when the U.S. suddently changed the strategy and the U.S. Vice President Dick Cheney spoke of the change in American strategic objective on Iraq, Germany reacted negatively. Germany felt that the U.S. had acted unilaterally by making a decision with worldwide impact without consulting its allies. Schroeder protested this absence of consultation and regarded it as a big mistake. As Schroder said, "Consultation is important, but consultation cannot mean that I get a phone call two hours in advance only to be told, 'We're going in." (Erlanger, 2002: A1).

Yet, the absence of consultation could be understood because the prospect of agreement by Germany to the U.S.'s war plan seemed very low. The U.S. knew that Germany would reject the plan and therefore consulted the matter with Britain only. ${ }^{3}$ However, from

met in Berlin in May 2002, they avoided talking about the issue because, "both knew that they held opposing views 
the German point of view, this indicated the U.S.'s contempt of its allies. German leaders felt that they were seen as a client rather than an independent state that should be on equal footing in their relationship with the U.S. (Kaim, 2003/2004: 134). Indication of Bush's administration of "go it alone" policy over Iraq and apparent unilateralist were regarded as strange and insulting to Germany. This dissappointed German leaders so that they declared bluntly not to support the policy regardless of the U.N.'s legal support for it.

Entering the election period on August 2002, the issue of German foreign policy over Iraq became a hot electoral topic. Schroeder took advantage of unfavorable German public mood over the U.S.'s war plan by intensifying his resistance against the policy. In a campaign, Schroeder declared that Germany would not provide troops or money to support the war despite the U.N.'s permission. This was because, to Schroeder, since the beginning, the reason for war was flawed. He called the war an adventure and asserted, "we're not available for adventures, and the time of cheque-book diplomacy is over once and for all." (cited in The Guardian, $5^{\text {th }}$ August 2002). In an interview on the late August 2002, Schroeder also reinforced his previous position on the war, saying that regime change would deteriorate the Iraqi problem and undermine the prospect of getting the U.N. inspectors allowed to enter Iraq (New York Times, 28 $8^{\text {th }}$ August 2002: A8). His statement was a response to Cheney's declaration that signaled the shift in American policy objective from disarming Saddam of WMD to regime change in Iraq.

German strong opposition to the war eventually worsened the relations between the two nations. Schroeder's strong statement along with those of his aides and government ministers have been regarded as too offensive to the Bush administration. The U.S. National Security Advisor Condolezza Rice and Secretary of Defense Donald Rumsfeld said those statements have made the relations between the two countries "poisoned." They accused German leaders had aroused antiAmerican sentiment in the German public (The
Economist, 26 ${ }^{\text {th }}$ September 2002). To the Bush administration, those statements could not be seen simply as electoral rethoric, but more than that, they reflected the German overconfidence about their approach to Iraq and feeling of ethical superiority to its powerfull ally (Larres, 2003: 25; Kissinger, 2002). The relationship between the two countries had plunged to such a low point that Bush did not even want to meet Schroeder personally during NATO Summit in Prague and Rumsfeld avoided meeting his German counterpart in a conference in Warsaw (Kaim, 2003/2004: 127).

Germany's decision not to enter the war seemed to confirm legitimacy argument. From the historical data, it was apparent that Germany actually had previously supported the U.S.'s war against terrorism including attempt to eliminate potential threat posed by Saddam Hussein's regime. In many public statements made by Schroeder and other German leaders, Germany would not be hesitant to send their troops overseas along with those of the U.S. if it would be authorized by the U.N.S.C. A U.N.'s mandate was important because this was the basis for justifying foreign policy to the public. However, to Germany, legitimacy was not only about the legal basis for an action. It was also about the action itself. German leaders defined the legitimate action in the context of non-use of force. This was evident in Schroeder's assertion that he would not support the war despite the U.N.'s mandate. At this point, we could see the existence of what Larres called "U.S.-German value gaps" (Larres, 2003/2004). Not only did the two countries perceived Saddam's regime differently, they also differed on how to deal with the regime.

Germany's foreign policy over the American war plan also reflected German identity as a pacifist country. Although Germany no longer adopted unconditional pacifism as indicated by its willingness to send peacekeeping mission abroad under the U.N.'s mandate, its anti-military principle is still strong (Kaim, 2003/2004: 135). Based on this identity, it is understandable that the way Germany deals with threats is different from the U.S. In response to terrorism, for example,

that could not be reconciled." (cited in Spiegel Online, 13 November 2010). 
Germany prefers "civilian" approach rather than military one: multilateralist and economic punishment (Kaim, 2003/2003: 137). This identity was reflected in its public mood towards the war which demonstrated strong rejection. In an "Iraq Survey" conducted by Gallup International on January 2003, around $50 \%$ of German respondents rejected the war under no circumstances (cited in Springford, 2003: 2). Furthermore, domestically, two governing coalitional parties, Social Democrats and Green parties tended to adopt pacifist, anti-Americanist and morally-led foreign policy principles (Kaim, 2003/2004: 135; Larres, 2003/2004: 24-25).

Nonetheless, Germany also understood that legitimacy is a social approval. This means that a legitimate action will depend so much on the community. If the community approves an action and see it acceptable, Germany can not reject it even though it is not in line with German values and principles. However, Germany will not support it either. Although this may pose a dilemma for Germany, its position will not opt out of multilateralism. This dilemma was revealed in Fischer's memoirs. Fischer recounted how he debated with Schroeder regarding Germany's position if France and Russia approved the U.N.S.C.'s resolution authorizing the U.S.'s war plan. To Fischer, being abstain from voting would be the only option available because Germany would not want to risk being isolated from the international community (cited in Spiegel Online, 1 $7^{\text {th }}$ February 2011).

\section{Conclusion}

This paper evaluates constructivist theory on the social conception of power hypothesizing that power is embedded in social relations among actors. Power understood this way assumes that state's ability to influence others depends on the legitimacy of its action from the perspective of international community. To constructivists, states tend to assess a country's action not only in terms of its means-end calculation but also in terms of its appropriateness with the norms of the international community. This assumption leads to a hypothesis that a country's response to other country's foreign policy will be based on whether or not the foreign policy instrument is legitimate. I test this hypothesis by examining how Britain and Germany responded to the U.S.'s policy against Iraq in 1991 and 2003.

As explained in the case studies above, legitimacy consideration may explain Germany's foreign policy response to the U.S.'s war plan in the second U.S invasion quite convincingly. However, it cannot explain well for the other three cases: Britain's foreign policy during the first and the second U.S.'s invasions and Germany's foreign policy during the first invasion. In the case of Britain's involvement in both the first and second invasion, special relationship between Britain and the U.S. may explain better. In the first invasion, for example, Thatcher's vigorous support for using force against Iraq was driven more by her attempts to get attention from the US and to be regarded as a staunch ally. Besides, she would also like to show Britain's great power status in the world. This could be seen from the fact that it was Britain which was more enthusiastic in supporting the war than the U.S. itself. Britain also tried hard to gather support in the U.N. to pass resolution authorizing the use of force against Iraq.

However, legitimacy may explain Britain's foreign policy response against Iraq. On many occasions, PM Thatcher declared that Iraqi invasion of Kuwait violated international law and Iraq had to withdraw its troops immediately. War was launched simply because Iraq failed to conform to the resolutions. Yet, material interests could also explain Britain's policy. Its close economic relations with Kuwait, Kuwait's huge investment in Britain, and the need for stable oil supply from Kuwait to the West in general, could also explain this policy.

In the second invasion, Britain once again got involved in the U.S.'s war policy since the beginning. Although some might argue that Blair's support for the U.S.'s war policy emerged after his personal meeting with Bush in the Crawford ranch, his minutes to his aides demonstrated clearly that he had harbored his own war plan against Saddam before that meeting. This fact indicated that legitimacy consideration towards U.S war policy could not account for Blair's support for the U.S. 
Thus, as suggested by some scholars, alternative explanations could be found in Blair's personal impression of Saddam regime. Blair seemed to regard Saddam as a serious threat that should be eliminated (Kauffman, 2004). On many public occassions, he uttered his belief on the danger of Saddam and considered any attempt to disarm him from his WMD as ineffective to eliminate this threat. Other convincing argument that can explain his policy against Iraq is strategic factor. Like what Thatcher did in 1990, Blair also believed that by allying himself with Bush in his war policy, he expected to influence the U.S.'s policy for Britain's advantage. Blair also explained this in several occasions, that the best way to control Bush's foreign policy is by having involved and allying himself with Bush (Dyson, 2006).

Legitimacy could not explain Germany's involvement in the Gulf War I either. From the evidence presented above, Germany participated in the war at the America's behest. Pressure from the U.S. and Germany's dependence on the U.S. for supporting German reunification might offer more convincing explanation. This could be seen from the fact that Germany participated in the war only after Baker's visit to Germany and criticism from the U.S. Congressmen. After all, Germany needed congressional support to ratify The Treaty on the Final Settlement With Respect to Germany (Unification Treaty) signed in Moscow on September 12, 1990 that would give united Germany full sovereignty in the following year (The Economist, $2^{\text {nd }}$ September 1990: 98). Therefore, there was a reciprocity in the policy where Germany contributed to the war under the expectation that the unification process would run smoothly and would be supported by U.S. and other great powers. Even though in relation to Iraqi behavior, German foreign policy might be based on legitimacy, the U.S.'s pressure and alliance dependence still explained better.

In the second invasion, legitimacy argument could explain German foreign policy well. We could see how Germany consistently conformed to 'legitimate' policy dealing with assumed Iraqi threat. To German leaders, the U.S.'s war against Iraq was illegitimate because some alternative policies had not been used. In line with international law, the U.N. Charter, and just war principles, war should be used as the last resort. Some classifed papers also vindicated that German officials attempted hard to thwart the war plan and pressed the U.S. government to use diplomatic approach to deal with Iraq (Spiegel Online, $24^{\text {th }}$ November 2010). Domestically, German leaders were also emboldened by public pressure conceiving the U.S.'s war plan as illegitimate and incompatible with the German identity as a pacifist and anti-militarist country. Although pragmatic reasons like electoral tactics might also underlie Schroeder's response to the plan, legitimacy remained dominant here. Electoral reasons might change the way Schroeder responded to the war plan, but the essence was similar: rejection to the war due to public hatred to the plan and the plan's incoherence with the German identity.

Some might argue that economic factors affected Germany's decision not to support the plan because Germany was in economic recession during the time so that it could not spend more for military program. While it was true that Germany was in recession those years (The Economist, $6^{\text {th }}$ January 2003; BBC News, 26 th February 2003), it was true as well from theoretical perspective that in economic crises, a country should increase spending to boost the economy. Therefore, seeing the German economy in 2002-2003, Germany should have supported war because this would have increased the aggregate spending and would help expand the economy (Keynesian war policy).

The analysis in the paper indicates that in most cases, states still predicate their responses to other countries' foreign policy on pragmatic reasons. Although logic of appropriateness may be factored in states' strategic calculation, during crises, strategic material interests may dominate. This is understandable given that during crises, decision has to be made within limited span of time, thus allowing few considerations regarded as very crucial only. Under this situation, leaders have to think in terms of material calculation of cost-benefits of an action. Thus, unless public pressure has been so intense, strategic choice will be more likely 
to be made based on material factors rather than ideational ones.

\section{Bibliography}

\section{Theoretical Bibliography Book and Journal Articles}

Barnett, M. \& Duvall, R. (2005) Power in international politics. International Organization, 59 (1) Winter, pp. 39-75.

Barnett, M. (2011) Social constructivism. In: Baylis, J., Smith, St., \& Owens, P. ed. The globalization of world politics. Oxford: Oxford University Press, pp. 150-165.

Bennett, A., Lepgold, J. \& Unger, D. (1994) Burden-sharing in the Persian Gulf War. International Organization, 48 (1) Winter, pp. 39-75.

Berenskoetter, F. (2007) Thinking about power. In: Berenskoetter, F. \& Williams, M.J. ed. Power in world politics. New York: Routledge, pp. 1-22.

Börner, Karl-Heinz. (1996) The future of German operation outside NATO. Parameter, Spring, pp. 62-72.

Clark, I. (2005) Legitimacy in international society. Oxford: Oxford University Press.

Dumbrell, J. (2006) A special relationship: Anglo-American relations in the Cold War and after. New York: Palgrave Macmillan.

Dyson, S.B. (2006) Personality and foreign policy: Tony Blair's Iraq decisions. Foreign Policy Analysis, 2 (3) July, pp. 289-306.

Finlan, A. (2003) The Gulf War 1991: essential histories. Oxford: Osprey Publishing.

Finnemore, M. \& Sikkink, K. (1998) International norm dynamics and political change. International Organization, 52 (4) Autumn, pp. 887917.

Franck, T.M. (1998) Legitimacy in the international system. American Journal of International Law, 82 (4), pp. 705759.

Freedman, L. \& Karsh, E. (1993) The Gulf conflict, 1990-1991: diplomacy and war in the new world order. N.J.: Princeton University Press.
George, A.L \& Bennet, A. (2005) Case studies and theory development in the social sciences. Massachusetts: MIT Press.

Gordon, P.H. \& Shapiro, J. (2004) Allies at war: America, Europe and the crisis over Iraq. New York: McGraw-Hill.

Haas, R.N. (2009) War of necessity, war of choice: a memoir of two Iraq wars. New York: Simon \& Schuster.

Hurd, I. (2007) Breaking and making norms: american revisionism and crises of legitimacy. International Politics, 44 (23) March/May, pp. 194-213.

Jepperson, RL., Wendt, A., \& Katzenstein, P. (1996) Norms, identity, and culture in national security. In: Katzenstein, K., ed. The culture of national security: norms and identity in world politics. New York: Columbia University Press, pp. 33-75.

Kaim, M. (2003/2004) Friendship under strain or fundamental alienation? Germany-US relations after the Iraq war. International Journal, 59 (1) Winter, pp. 127-143.

Kaufmann, C. (2004) Threat inflation and the failure of the marketplace of ideas: the selling of the Iraq war. International Security, 29 (1) Summer, pp. 5-48.

Klotz, A. (1995) Norms reconstituting interests: global racial equality and U.S. sanctions against South Africa. International Organization, 49 (3) Summer, pp. 451-478.

Krasner, S.D. (1982) Structural causes and regime consequences: regimes as intervening variables. International Organization, 36 (2), Spring, pp. 185205.

Larres, K. (2003) Mutual incomprehension: U.S.-German value gaps beyond Iraq. The Washington Quarterly, 26 (2) Spring, pp. 23-42.

Matthews, K. (1993) The Gulf conflict and international relations. New York and London: Routledge.

Moore, J.N. (1992) Crisis in the Gulf: enforcing the rule of law. New York: Oceana Publication.

Mueller, J. (1994) Policy and opinion in the Gulf War. Chicago: University of Chicago Press. 
Nye, J.S. (2002) The paradox of American power. Oxford: Oxford University Press.

Price, R. \& Reus-Smit, C. (1998) Dangerous liaisons? Critical international theory and constructivism. European Journal of International Relations, 4 (3), pp. 259-294.

Reus-Smit, C. (2004) American power and world order. Cambridge: Polity Press.

. (2005) Constructivism. In: Burchill, S., Linklater, A., Richard, D., Donnelly, J., Paterson, M., Reus-Smit, C. \& True, J. ed. Theories of international relations. New York: Palgrave Macmillan, pp. 188212

(2007) International crises of legitimacy. International Politics, 44 (23) March/May, pp. 157-174.

Sharp, J.M.O. (2003/2004) Tony Blair, Iraq and the special relationship: poodle or partner?. International Journal, 59 (1) Winter, pp. 59-86.

Simons, G. (2004) Iraq: from Sumer to postSaddam. New York: Palgrave Macmillan.

Suchman, M. (1995) Managing legitimacy: strategic and institutional approaches. Academy of Management Review, 29 (3), pp. 571-610.

Tannenwald, N. (1999) The nuclear taboo: the United States and the normative basis of nuclear non-use. International Organization, 53 (3) Summer, pp. 433468.

Van Evera, S. (1997) Guide to methods for students of political science. Ithaca: Cornell University Press.

Wendt, A. (1992) Anarchy is what states make of it: the social construction of power politics. International Organization, 46 (2) Spring, pp. 391-425.

Wendt, A. (1995) Constructing international politics. International Security, 20 (1) Summer, pp. 71-81.Wendt, A. (1999) Social theory of international politics. Cambridge: Cambridge University Press.

Woodward, B. (2004) Plan of attack. New York: Simon \& Schuster.

\section{Online Article}

(2002) America and Germany: the poisoned relationship and one that will be hard to detoxify [Online], The Economist. Available from: <http://www.economist.com/node/135 9855> [Accessed 18 December 2012].

(2003) Germany's not working [Online], The Economist. Available from: $<$ http://www.economist.com/node/152 1165> [Accessed 19 December 2012].

(2003) German economy at a standstill [Online], BBC News. Available from: <http://news.bbc.co.uk/2/hi/business/ 2800003.stm $>$ [Accessed 19 December 2012]

(2006) Schröder on Iraq "the mother of all misjudgements [Online], Spiegel Online. Available from: <http://www.spiegel.de/international/ schroeder-on-iraq-the-mother-of-allmisjudgements-a-444748.html>

[Accessed 18 December 2012].

(2010) Memoirs trigger new row over Iraq Bush made empty promises to Schröder [Online], Spiegel Online. Available from:

$<$ http://www.spiegel.de/international/ world/memoirs-trigger-new-row-overiraq-bush-made-empty-promises-toschroeder-a-728973.html $>$ [Accessed 18 December 2012].(2003) Memorandum opposing U.S. Iraq policy. New York Times, 25 February, p. A14.

(2011) 'I am not convinced' Joschka Fischer on Germany's 'no' to the Iraq war [Online], Spiegel Online. Available from:

$<$ http://www.spiegel.de/international/ germany/i-am-not-convinced-joschkafischer-on-germany-s-no-to-the-iraqwar-a-745901.html?> [Accessed 18 December 2012]

Harnden, T. (2010) Gerhard Schroeder accuses George W Bush of 'not telling truth' in memoirs [Online], The Telegraph. Available from: <http://www.telegraph.co.uk/news/wo rldnews/us-politics/8124170/GerhardSchroeder-accuses-George-W-Bush-of- 
not-telling-truth-in-memoirs.html>

[Accessed 18 December 2012].

Hooper, J. (2002) German leader says no to Iraq war [Online], Guardian. Available from:

<http://www.guardian.co.uk/world/20 02/aug/o6/iraq.johnhooper $>$ [Accessed 18 December 2012].

Kissinger, H.A. (2002) No place for 'made in Berlin' unilateralism in this age [Online], Houston Chronicle. Available from:

<http://www.chron.com/opinion/outlo ok/article/No-place-for-made-in-

Berlin-unilateralism-in-2119704.php>

[Accessed 18 December 2012].

Royce, K. (1990) Middle East crisis secret offer Iraq sent pullout deal to U.S [Online], Newsday Washington Bureau. Available from:

<http://www.scribd.com/doc/3896981

3/MIDDLE-EAST-CRISIS-Secret-

Offer-Iraq-Sent-Pullout-Deal-to-U-S-

ALL-EDITIONS > [Accessed 15

December 2012].

Spörl, G. \& Wiegrefe, K. (2010) Incompatible interests the truth blurs for Bush and Schröder [Online], Spiegel Online, Available from: <http://www.spiegel.de/international/ world/incompatible-interests-thetruth-blurs-for-bush-and-schroeder-a729047.html> [Accessed 18 December 2012].

Springford, J. (2003) 'Old' and 'new' Europeans united: public attitudes towards the Iraq war and US foreign policy [Online]. London: Center for European Reform. Available from: Background Brief http://www.cer.org.uk/pdf/back_brief _springford_deco3.pdf [Accessed 18 December 2012].

Wiegrefe, K. (2010) Berlin efforts to prevent Iraq invasion classified papers prove German warnings to Bush [Online], Spiegel Online. Available from: <http://www.spiegel.de/international/ germany/berlin-efforts-to-preventiraq-invasion-classified-papers-provegerman-warnings-to-bush-a- 730979.html $>$ [Accessed 18 December 2012].

Thatcher, M. (1990) Joint press conference with President Bush (Iraq invasion of Kuwait) [Online]. Available from: <http://www.margaretthatcher.org/d ocument/108170 $>$ [Accessed 15 December 2012].

\section{Library Database}

(1990) A strange and motley army. The Economist, 22 September, p. 46.

(1990) Confrontation in the Gulf; proposals by Iraqi president: excerpts from his address. New York Times, 13 August, p. A8.

(1990) Just like old times. The Economist, 1 September, p. 51.

Bernstein, R. (2003) For old friends, Iraq bares a deep rift. New York Times, February 2014, p. A1.

Erlanger, S. (2002) Iraq speech by Cheney is criticized by Schroder. New York Times, August 28, p. A8

- (2002) German leader's warning: war plan is a huge mistake. New York Times, September 5, p. A1.

Frankel, G. (1990) Britain first to join multinational force. Washington Post, 9 August, p. A37.

. (1991) Britain reclaiming role as top U.S. ally. Washington Post, 19 January, p. A23.

Friedman, T.L. (1990) Confrontation in the Gulf: behind Bush's hard line; Washington considers a clear Iraqi defeat to be necessary to bolster its Arab allies. New York Times, 22 August, p. A1.

Gibowski, W.G. (1991) Germans support war against Iraq. New York Times, February 7, p. A24.

Goshko, J.M. (1991) Germany to complete contribution toward Gulf War costs Thursday. Washington Post, 27 March, p. A26.

Guha, K. \& Dinmore, G. (2003) War opponents vow to block new UN resolution. Financial Times, 6 March.

Kinzer, S. (1991) German are told of Gulf-War role: Kohl Pledges more Israel aid, saying Germany has no 'safe little 
corner. New York Times, 31 January, p.

A14.

. (1991) Anti-war protest is staged in Bonn: many avoid singling out U.S. and fault home concerns. The New York Times, 27 January, p. 17.

. (1991) Gulf War sets off crisis for Germans: uncertainty over future role in military confrontations fuels soulsearching. New York Times, 17 February, p. 15.Kinzer, S. (1991) Uniform support and hope for end. New York Times, 25 February, p. A16.

Sciolino, E. (2002) As U.S. pursues a verbal war against Iraq, other nations raise their voices. New York Times, 1 September, p. 16.Webster, P. (1991) Parties agreed on need to destroy Iraqi war machine. Times, 29 January, p. 2.

Weisman, S.R. (2003) Refusal by French and Germans to back U.S. on Iraq has undercut powell's position. New York Times, 24 January, p. A10.

Whitney, C.R. (1991) Polls show support for war, even in Germany. New York Times, 29 January, p. A14.Wood, N. \& Bremner, C. (1990) Thatcher hits at Europeans' Gulf efforts. Times, 31 August, p. 1.

\section{Primary Documents}

Iraq Inquiry Commission. (2002, March). Prime Minister Blair's Minute to Powell.

Iraq Inquiry Commission. (2002, July). Powell's Minute to Prime Minister.

Iraq Inquiry Commission. (2002, September). Ryecroft's Minute to Prime Minister.

Iraq Inquiry Commission. (2002, September). Manning's Minute to Prime Minister. 
